\title{
IS IT POSSIBLE TO ESTIMATE LABOUR PRODUCTIVITY IN THE CZECH HIGHER EDUCATION?
}

\begin{abstract}
This paper deals with the issues of estimation of labour productivity in the Czech higher education institutions (HEIs) and also at the Faculties of Economics of the Czech HEIs. We focus on the period between the years 2006 and 2010. At first, we analyze the influence of labour productivity on the level of average wages of academic staff in 2010. In this case, we consider that the labour productivity consist of two parts - teaching productivity (the total number of students adjusted by the coefficient of economical difficulty per academic staff) and research productivity (the total number of publication points per academic staff). Secondly, we compare the changes between teaching productivity in the period between the years 2006 and 2010 and the changes between average wages adjusted of average inflation rate at the level of HEIs and at the level of the Faculties of Economics.
\end{abstract}

\section{Key Words}

Higher education institutions, correlation, labour costs, labour productivity, productivity in non-market industries
Kristýna Vltavská, Jakub Fischer

University of Economics, Prague

kristyna.vltavska@vse.cz

ARTICLE INFO

Article type

Full research paper

doi: 10.7160/eriesj.2013.060104

Article history

Received: October 14, 2012

Received in revised form: December 20, 2012

Accepted: January 18, 2013

Available on-line: March 31, 2013

Vltavská, K., Fischer, J. (2013) “Is It Possible to Estimate Labour Productivity in the Czech Higher Education", Journal on Efficiency and Responsibility in Education and Science, Vol. 6, No. 1, pp. 34-45, ISSN 1803-1617, [on-line] www.eriesjournal.com/_papers/article_194.pdf 


\section{Introduction}

In 2009 the White Paper on Tertiary Education ${ }^{1}$ was brought out and the discussion of tertiary education reform has significantly gained on importance since then. It brought questions of quality of higher education institutions (hereafter: HEIs) and academic staff as well. That is why we decided to present analyses dealing with labour productivity and labour costs at the Czech HEIs and at the Faculties of Economics.

According to The Principles and Rules of Funding of HEIs², public funds (subsidies from the Ministry of Education, Youth and Sports for educational activities of HEIs) are allocated to the level of HEIs and not to the level of faculties. Allocation of the university budget to individual faculties fully depends on autonomous decision of the Academic Senate of HEI (the Senate has to confirm the Rector's proposal of the HEI's budget ${ }^{3}$ ).

The main goal of the paper is to evaluate whether the allocation of HEIs' budgets on faculties leads to the significant relation between teaching and research performance of academic staff on one hand and average wages on the other hand at faculties related on economic branches of study.

Measurement of performance and productivity in non-market industries is a very demanding issue. While the productivity in market industries can be considered as a ratio of sales (adjusted of changes in own-produced inventories) to employment, in non-market industries we cannot measure sales as an output. As a key reference to an issue of non-market-industry productivity 1 http://www.msmt.cz/reforma-terciarniho-vzdelavani/bila-kniha?hig hlightWords=white+paper+tertiary

2 The Principles and Rules of Funding of HEIs, Czech language (2012d): http://www.msmt.cz/ekonomika-skolstvi/zasady-a-pravidla-financovaniverejnych-vysokych-skol-pro

3 Paragraph 9, the Law on Higher Education Institutions (2012c): http://www.msmt.cz/file/22282 we consider Atkinson Review (ONS, 2005); chapter 9 is devoted to education. Consequences of differences between marketindustry productivity and non-market-industry productivity including estimates of production function for non-market industries are presented by Simpson (2006). However, both Atkinson and Simpson use British data and in relation to education they take into account mainly basic and secondary education. Productivity in higher education and approaches to its measurement are defined by Gates and Stone (1997). As most important in this paper we consider terminological differences between terms efficiency and effectiveness. Jablonsky (2011) analysed the efficiency of teaching and research activities at the level of departments using DEA methodology. Huzvar and Rigova (2012) used DEA methodology for analysis of relations between academic process and funding of public HEIs. Finally, relation between productivity and policy making is introduced by Callan (2007).

The aims of the article are (i) to estimate the relation between average wages and academic performances and (ii) to compare differences between changes in labour productivity and changes in labour costs (represented by the average wages) both at the Czech HEIs and at the Faculties of Economics between the years 2006 and 2010.

\section{Material and Methods}

For the analysis we use data from the Ministry of Education, Youth and. This data set includes data on average wages of academic staff, number of academic staff (MŠMT, 2012a), average number of students (MŠMT, 2012b) and the sum of the publication points (called "RIV points") using the "Methodology of Evaluation of Research Institutions Results and of Evaluation of Finished Programmes 2011" (RVVI, 2011). All the analyses 
are presented only on the public HEIs excluding artistic HEIs which are the outliers ${ }^{4}$. Colleges are not included into the analysis. Due to the lack of the dataset needed for the analysis we had to exclude the Faculty of Economics of University of South Bohemia in České Budějovice and two newest nonuniversity HEIs ${ }^{5}$.

Firstly, we would like to find out if the average wage of the academic staff is the function of labour productivity and if there is a correlation between these variables. Labour productivity in this case consists of two self-independent parts - teaching (number of student adjusted by the coefficient of economical difficulty per academic staff) and research (RIV points per academic staff).

Multiple regression and multiple correlation coefficients ${ }^{6}$ were used for the analysis. The analysis is based on the hypothesis that changes in the dependent variable $y$ (average wage) are caused by two independent variables $x_{1}$ and $x_{2}$ (teaching productivity and research productivity) which is presented by the formula:

$$
y=\beta_{0}+\beta_{1} x_{1}+\beta_{2} x_{2}
$$

By using the method of least squares we can estimate the multiple regression function

$$
Y=b_{0}+b_{y x 1 . . x 2} x_{1}+b_{y x 2 . x 1} x_{2}
$$

For the discussion about the relation between the variables the multiple correlation coefficient $r_{y \times 1 . \times 2 \ldots x p}$ and the coefficient of determination $\mathrm{R}^{2}$ were used.

\footnotetext{
$4 \quad$ The average coefficient of economical difficulty of the artistic HEIs reaches 5.9. It is much higher than the rest of the HEIs.

5 We do not have RIV points of the non-university HEIs .

6 For more information see Hindls et al (2004).
}

The second part of the paper is focused on the analysis of competitiveness of the HEIs and Faculties of Economics by using the condition modified to the non-market industry

where $C$...labour costs ${ }^{7}$

$$
C_{1} / Y_{1}<C_{0} / Y_{0^{\prime}}
$$

$$
Y \text {...number of students }
$$

After an adjustment we can state

$$
C_{1} / C_{0}<Y_{1} / Y_{0^{\prime}}
$$

which could be interpreted as a requirement of slower increase of labour costs in comparison with the change of number of students.

After the division of both parts of the inequation by the labour force index represented by the index of number of academic staff, we get

$$
C_{1} / C_{0}: L_{1} / L_{0}<Y_{1} / Y_{0}: L_{1} / L_{0},
$$

and after the algebraic adjustment

$$
C_{1} / L_{1}: C_{0} / L_{0}<Y_{1} / L_{1}: Y_{0} / L_{0} .
$$

It means that average labour costs should increase more slowly than labour productivity ${ }^{8}$. Alternatively, we can consider compensation of employees as $C$, but in short term we can suppose the constant ratio of social contributions to wages and salaries. It implies that the inequation (4) expresses the relation between average wages and labour productivity. Since we estimate real labour productivity by using natural indicator, the average wage has to be real too. It is necessary to take into account inflation represented by consumer price index ${ }^{9}$.

\footnotetext{
$7 \quad$ Labour costs are broadly described in Jílek, Moravová (p. 129, 2007). 8 The competitiveness concept is only one of the possible approaches. In the case of an increase of the quality of education (e.g. employment more qualified academic staff) the condition would be applied vice versa. $9 \quad$ See Hindls et al. (p. 381, 2004).
} 


\section{Results}

\section{Higher Education Institutions}

For the analyses we use the data on number of students of the HEIs, the coefficient of economical difficulty, number of academic staff, average wage, RIV points (see Table 1 and Table 2).

Firstly, we discussed whether average wage is the function of labour productivity represented by teaching productivity $\left(x_{1}\right)$ and research productivity $\left(x_{2}\right)$.

$$
y=19069.8+303.92 x_{1}+76.62 x_{2}
$$$$
\text { (4.64) (3.31 (4.29) }
$$

From the results we can say that increase in teaching productivity (the increase of one student per academic staff) evokes increase in average wage of $303.92 \mathrm{CZK}$. One point of increase in RIV points per person leads to increase in the average wage of 76.62 CZK.

The values of characteristics are as follows:

$$
\mathrm{R}^{2}=0.561, \mathrm{r}_{\mathrm{x} 1 \times 2}=-0.37, \mathrm{r}_{\mathrm{yx} 1}=0.53, \mathrm{r}_{\mathrm{yx} 2}=0.29
$$

\begin{tabular}{|c|c|c|c|c|c|c|c|}
\hline & \multicolumn{3}{|c|}{2006} & \multicolumn{3}{|c|}{2010} & \multirow[b]{2}{*}{ RIV points } \\
\hline & $\begin{array}{l}\text { D. } \\
\text { हैँ } \\
\text { Dे }\end{array}$ & 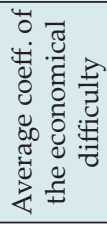 & 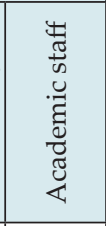 & $\begin{array}{l}\text { 苞 } \\
\text { D̃ } \\
\text { के }\end{array}$ & 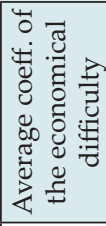 & 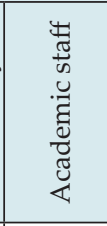 & \\
\hline CTU & 22747 & 1.815 & 1411.7 & 22517 & 1.865 & 1500.4 & 211795.95 \\
\hline CULS & 16748 & 1.611 & \begin{tabular}{|l|}
498.7 \\
\end{tabular} & 20877 & 1.584 & 586.0 & 39260.67 \\
\hline USB & 9984 & 1.530 & 566.9 & 12593 & 1.506 & 588.0 & 65244.23 \\
\hline MU & 32483 & 1.417 & 1335.1 & 39500 & 1.406 & 1414.9 & 197255.59 \\
\hline MENDELU & 8769 & 1.881 & 416.6 & 10440 & 1.758 & 507.4 & 37075.97 \\
\hline UO & 8485 & 1.458 & 354.3 & 9967 & 1.505 & 446.8 & 23416.61 \\
\hline SU & 5524 & 1.253 & 214.5 & 8811 & 1.243 & 290.9 & 12795.60 \\
\hline TUL & 8178 & 1.433 & 516.0 & 9453 & 1.404 & 549.9 & 25652.96 \\
\hline UHK & 7303 & 1.372 & 351.7 & 8910 & 1.438 & 388.8 & 10505.59 \\
\hline UJEP & 9106 & 1.669 & 395.5 & 10575 & 1.663 & 458.0 & 13999.44 \\
\hline $\mathrm{CU}$ & 46101 & 1.256 & 3219.3 & 49775 & 1.238 & 3465.3 & 513337.71 \\
\hline UPA & 8567 & 1.503 & 467.4 & 10604 & 1.485 & 513.0 & 56924.88 \\
\hline PU & 18887 & 1.688 & 1034.9 & 21935 & 1.631 & 1143.3 & 122834.71 \\
\hline TBU & 9906 & 1.555 & 309.4 & 13113 & 1.617 & 396.5 & 22529.43 \\
\hline UVPS & 2552 & 3.164 & 221.8 & 2919 & 3.162 & 259.3 & 18838.34 \\
\hline VŠB-TUO & 21451 & 1.509 & 910.0 & 22353 & 1.498 & 1016.3 & 52307.64 \\
\hline VŠE & 16012 & 1.084 & 566.3 & 19271 & 1.089 & 582.5 & 24029.97 \\
\hline ICT & 3973 & 2.745 & 416.9 & 3647 & 2.721 & 414.5 & 79556.49 \\
\hline BUT & 20736 & 1.701 & 971.2 & 22211 & 1.690 & 997.6 & 134933.71 \\
\hline UWB & 15650 & 1.301 & 764.6 & 16469 & 1.360 & 822.1 & 62430.50 \\
\hline
\end{tabular}

Tab. 1: Number of students, the average coefficient of economical difficulty, number of academic staff, RIV points, public HEIs, 2006 and $2010^{10}$ 
From the results and the t-statistics (presented under the regression model) we can see that both the variables are significant (5\% level of significance). There is positive correlation between average wage and teaching productivity and there is positive correlation between average wage and research productivity. It means that increase in teaching productivity (represent by students per academic staff) causes the increase in average wage and increase in research productivity cause the increase in average wage as well. There is no multicollinearity ${ }^{11}$ (there is weak negative correlation between teaching productivity and research productivity, which means that increase in teaching productivity cause decreasing at the research productivity). It means that the model is estimated right. It is necessary to note that this model presents only part of the average wage.

The second part of the analysis focuses on the average labour costs (represent by real average wage) and teaching productivity (measured as the ratio of students adjusted by the coefficient of the economical difficulty per academic staff) among Czech HEIs between the years 2006 and 2010.

From the results (see table 3 ) one can see that there are some differences in teaching productivity and average labour costs among 20 Czech HEIs. The biggest difference between teaching productivity and labour costs during the period 2006 and 2010 was achieved at the Institute of Chemical Technology Prague (ICT). The total gap in 4 years was about 19 per cent. On the other hand teaching productivity increased more quickly than labour costs especially at the University of Hradec Králové (UHK). Teaching productivity increased of 15.68 per cent in the period in question. Average labour costs at the University of Hradec Králové decreased of 12.38 per cent.

\begin{tabular}{|c|c|c|c|c|c|}
\hline & \multicolumn{2}{|c|}{ average wage } & & \multicolumn{2}{|c|}{ average wage } \\
\hline & 2006 & 2010 & & 2006 & 2010 \\
\hline CULS & 43085 & 48654 & SU & 30363 & 35161 \\
\hline ICT & 35218 & 43697 & VŠB-TUO & 34209 & 35155 \\
\hline MU & 36528 & 42958 & USB & 29830 & 34625 \\
\hline CTU & 35988 & 40677 & $\mathrm{UO}$ & 29401 & 34317 \\
\hline BUT & 35267 & 38986 & TBU & 31378 & 33840 \\
\hline VŠE & 34411 & 38239 & UJEP & 27977 & 33165 \\
\hline MENDELU & 34205 & 36547 & UWB & 30718 & 33135 \\
\hline UPA & 33887 & 36152 & TUL & 25606 & 32321 \\
\hline PU & 30136 & 35849 & UVPS & 29707 & 30474 \\
\hline CU & 29020 & 35424 & UHK & 28854 & 28340 \\
\hline
\end{tabular}

Tab. 2: Average wage, public HEIs, 2006 and 2010

When we compare this result with the first estimation presented in Fischer, Vltavská (2011) which was done for the period between the years 2004 and 2009 we can see that the biggest difference between teaching productivity and labour costs during the period in question was achieved at the University of Ostrava. The total gap in 5 years was about 31 per cent. On the other hand teaching productivity increased more quickly than labour costs especially at the University of Economics in Prague. Teaching productivity increased of 23.81 per cent in the period in question. Average labour costs at the University of Economics increased of 6.82 per cent. 


\begin{tabular}{|c|c|c|c|c|c|c|c|}
\hline & $\begin{array}{l}\frac{n}{\omega} \\
\dot{0}\end{array}$ & 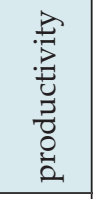 & 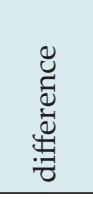 & & $\begin{array}{l}0 \\
\text { के } \\
\text { o }\end{array}$ & 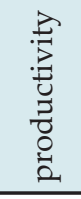 & 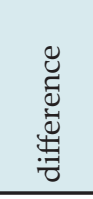 \\
\hline UHK & -12.38 & 15.68 & 28.6 & CULS & 0.74 & 4.32 & 3.58 \\
\hline VŠE & -0.87 & 17.49 & 18.36 & VŠB-TUO & -8.33 & -7.38 & 0.94 \\
\hline UPA & -4.83 & 11.42 & 16.25 & MENDELU & -4.69 & -8.66 & -3.97 \\
\hline USB & 3.55 & 19.76 & 16.21 & PU & 6.12 & 1.59 & -4.53 \\
\hline SU & 3.31 & 16.73 & 13.43 & CTU & 0.83 & -4.29 & -5.12 \\
\hline TBU & -3.79 & 7.48 & 11.27 & UJEP & 5.75 & -0.08 & -5.83 \\
\hline $\mathrm{MU}$ & 4.91 & 13.88 & 8.97 & TUL & 12.60 & 6.31 & -6.29 \\
\hline UVPS & -8.49 & -2.27 & 6.22 & UO & 4.13 & -3.90 & -8.03 \\
\hline UWB & -3.77 & 2.33 & 6.10 & $\mathrm{CU}$ & 8.89 & -1.11 & -10.01 \\
\hline BUT & -1.38 & 3.62 & 5.00 & ICT & 10.69 & -8.50 & -19.19 \\
\hline
\end{tabular}

Tab. 3: Change in real teaching productivity and average real labour costs, public HEIs (2006 - 2010, annual growth, \%)

\section{Faculties of Economics}

The dataset used for the analyses contain number of students of the Faculties of Economics of public HEIs, the average number of academic staff, average wage, RIV points (see Table 4 and Table 5).

First part of the analysis is devoted to the analyses of the relationship between teaching productivity $\left(x_{1}\right)$ and research productivity $\left(x_{2}\right)$.

$$
\begin{gathered}
y=14085+508.4 x_{1}+67.6 x_{2} \\
(1.87) \quad(1.24) \quad(2.81)
\end{gathered}
$$

We can conclude that the increase in the education part of teaching productivity by one causes the increase in average wage by 508.4 CZK. One point of increase in RIV points per person leads to the increase in the average wage by $67.6 \mathrm{CZK}$ (both under the condition of ceteris paribus).

The values of characteristics are as follows:

$$
\mathrm{R}^{2}=0.37, \mathrm{r}_{\mathrm{x} 1 \times 2}=-0.072, \mathrm{r}_{\mathrm{yx} 1}=0.56, \mathrm{r}_{\mathrm{yx} 2}=0.21
$$

The t-statistics (presented under the regression model) show that variable "teaching productivity" is statistically significant at $10 \%$ level of significance. A weak negative correlation between teaching productivity and research productivity was traced. That means that an increase in the teaching productivity caused a decrease in the research productivity represented. On the other hand, there is a positive correlation between average wage and the teaching productivity and average wage and research productivity. One can see the link between the results of the HEIs and the Faculties of Economics. There is no multicollinearity (10\% level of significance). 


\begin{tabular}{|c|c|c|c|c|c|c|}
\hline \multirow[b]{2}{*}{ Faculty } & \multirow[b]{2}{*}{ 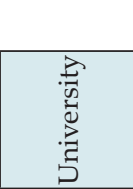 } & \multicolumn{2}{|c|}{2006} & \multicolumn{2}{|c|}{2010} & \multirow[b]{2}{*}{ 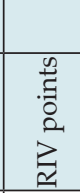 } \\
\hline & & 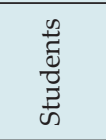 & 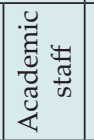 & 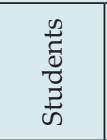 & 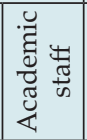 & \\
\hline of Social Sciences & $\mathrm{CU}$ & 3128.5 & 125.8 & 4104.5 & 137.3 & 14136 \\
\hline $\begin{array}{l}\text { of Social and Economic } \\
\text { Studies }\end{array}$ & UJEP & 2080.5 & 55.6 & 2199.5 & 67.2 & 321 \\
\hline $\begin{array}{l}\text { of Economics and } \\
\text { Administration }\end{array}$ & $\mathrm{MU}$ & 3520.0 & 86.6 & 4452.5 & 92.8 & 3060 \\
\hline $\begin{array}{l}\text { School of Business } \\
\text { Administration in Karvina }\end{array}$ & SU & 2635.0 & 95.0 & 4384.5 & 107.6 & 2581 \\
\hline of Economics & UWB & 2208.5 & 62.6 & 2311.5 & 61.2 & 492 \\
\hline of Economics & TUL & 1386.0 & 71.4 & 2080.5 & 83.1 & 2037 \\
\hline $\begin{array}{l}\text { of Economics ar } \\
\text { Administration }\end{array}$ & UPA & 2381.5 & 69.4 & 2638.5 & 78.5 & 3925 \\
\hline $\begin{array}{l}\text { of Business and } \\
\text { Management }\end{array}$ & BUT & 2185.5 & 63.7 & 2758.0 & 81.2 & 1961 \\
\hline of Economics & VŠB-TUO & 5594.0 & 175.0 & 6539.0 & 175.5 & 4995 \\
\hline $\begin{array}{l}\text { of Management and } \\
\text { Economics }\end{array}$ & TBU & 3197.0 & 72.3 & 3418.5 & 83.9 & 2927 \\
\hline of Finance and Accounting & VŠE & 2576.0 & 79.5 & 3176.0 & 81.6 & 5392 \\
\hline of International Relations & VŠE & 3835.0 & 170.3 & 4712.5 & 171.8 & 5252 \\
\hline of Business Administration & VŠE & 3260.5 & 91.5 & 3778.0 & 105.9 & 3435 \\
\hline of Informatics and Statistics & VŠE & 2575.5 & 111.1 & 3332.0 & 100.3 & 4809 \\
\hline of Economics & VŠE & 2231.5 & 55.8 & 2571.5 & 65.2 & 3936 \\
\hline of Management & VŠE & 1284.5 & 39.5 & 1436.5 & 38.6 & 1201 \\
\hline $\begin{array}{l}\text { of Economics and } \\
\text { Management }\end{array}$ & CULS & 7144.0 & 168.6 & 9462.0 & 185.7 & 5276 \\
\hline of Business and Economics & MENDELU & 2831.5 & 96.9 & 3658.0 & 113.9 & 5636 \\
\hline
\end{tabular}

The productivity analysis represents the second part of the paper. We estimated the average labour cost (real average wage) and teaching (labour) productivity (the ratio of students adjusted by the coefficient of the economical difficulty per academic staff) among the Faculties of Economics between the years 2006 and 2010.

When comparing the development of teaching productivity and average labour costs, the differences between the individual quantities may take the form of percentage. This proved better for our purposes since it clearly illustrates the change in the growth. In 2010, the highest average wage is reached at the Faculty of Economics and Management of the Czech University of Life Sciences Prague (CULS), followed by the Faculty of Economics and Administration of Masaryk University and the Faculty of Finance and Accounting of the University of Economics, Prague (see Table 5). On the other hand, the wage is the lowest at Faculty of Economics of the West Bohemia University (UWB). Also some methodological issues mentioned above such as additional workloads complicate the analysis and interpreting of its results.

Tab. 4: Average number of students, average number of academic staff, RIV points, Faculties of Economics, 2006 and 2010 


\begin{tabular}{|c|c|c|c|}
\hline \multirow[b]{2}{*}{ Faculty } & \multirow[b]{2}{*}{ HEI } & \multicolumn{2}{|c|}{ average wage } \\
\hline & & 2006 & 2010 \\
\hline of Economics and Management & CULS & 43963 & 54551 \\
\hline of Economics and Administration & MU & 39288 & 44654 \\
\hline of Finance and Accounting & VŠE & 38933 & 43823 \\
\hline of Economics and Administration & UPA & 38353 & 38214 \\
\hline of Business Administration & VŠE & 34919 & 37060 \\
\hline of Economics & VŠE & 34030 & 36554 \\
\hline of Informatics and Statistics & VŠE & 32374 & 36442 \\
\hline of Business and Economics & MENDELU & 35634 & 36105 \\
\hline of Management & VŠE & 35326 & 35682 \\
\hline of Social Sciences & $\mathrm{CU}$ & 30258 & 35096 \\
\hline $\begin{array}{l}\text { School of Business Administration } \\
\text { in Karvina }\end{array}$ & SU & 26585 & 34769 \\
\hline of International Relations & VŠE & 30361 & 34482 \\
\hline of Economics & VŠB-TUO & 31941 & 33936 \\
\hline of Economics & TUL & 27559 & 32614 \\
\hline of Social and Economic Studies & UJEP & 29477 & 32570 \\
\hline of Business and Management & BUT & 28837 & 31074 \\
\hline of Management and Economics & TBU & 26080 & 28079 \\
\hline of Economics & UWB & 32472 & 27335 \\
\hline
\end{tabular}

Tab. 5: Average wage, Faculties of Economics, 2006 and 2010

Table 6 presents the results of productivity analysis. One can see that there are some differences in teaching productivity and average labour costs among Faculties of Economics. At almost all Faculties of Economics, increase in teaching productivity is higher than in average wages. It could be explained by three causes. Firstly, the increase in number of students recorded between 2006 and 2010 had started at the beginning of 2000s. Secondly, due to the economic recession and fiscal restrictions the total budget for public universities decreased from 2009. Thirdly, the increase in number of students is realized mainly in economic branches of studies. But, there is a difference between individual Faculties of Economics. The highest difference between teaching productivity and real labour costs is higher than 40 percentage points (Faculty of Informatics and Statistics, University of Economics, Prague), but, on the other hand, at two faculties the decrease in productivity is higher than decrease in real labour costs. 


\begin{tabular}{|l|c|c|c|c|}
\hline Faculty & VŠE & 0.42 & 43.24 & 42.82 \\
\hline of Informatics and Statistics & UWB & -24.90 & 7.12 & 32.02 \\
\hline of Economics & SU & 16.67 & 46.86 & 30.19 \\
\hline $\begin{array}{l}\text { School of Business Administration } \\
\text { in Karvina }\end{array}$ & VŠE & -9.89 & 14.34 & 24.23 \\
\hline of Management & TUL & 5.57 & 29.03 & 23.45 \\
\hline of Economics & VŠB-TUO & -5.22 & 16.59 & 21.81 \\
\hline of Economics & VŠE & 1.32 & 21.83 & 20.52 \\
\hline of International Relations & VŠE & 0.41 & 20.15 & 19.74 \\
\hline of Finance and Accounting & MENDELU & -9.61 & 9.88 & 19.49 \\
\hline of Business and Economics & CU & 3.47 & 20.19 & 16.72 \\
\hline of Social Sciences & MU & 1.39 & 18.01 & 16.62 \\
\hline of Economics and Administration & CULS & 10.69 & 20.26 & 9.57 \\
\hline of Economics and Management & UPA & -11.11 & -2.00 & 9.12 \\
\hline of Economics and Administration & VŠE & -5.32 & 0.08 & 5.40 \\
\hline of Business Administration & BUT & -3.87 & -1.01 & 2.87 \\
\hline of Business and Management & VŠE & -4.18 & -1.45 & 2.72 \\
\hline of Economics & TBU & -3.95 & -7.88 & -3.92 \\
\hline of Management and Economics & UJEP & -1.43 & -12.47 & -11.04 \\
\hline of Social and Economic Studies & V̌n \\
\hline
\end{tabular}

Tab. 6: Change in real labour productivity and average real labour costs, Faculties of Economics (2006 - 2010, annual growth, \%)

\section{Discussion}

At the analysis of relations between wages and productivity of the faculties we can see significantly lower level of $\mathrm{R}^{2}$ comparing to the analysis at the level of (whole) HEIs. From our point of view it is possible to explain lower $\mathrm{R}^{2}$ by several reasons. Firstly, there could be some redistributive processes within HEIs (support of weaker faculties). Secondly, there are some methodological issues which can influence the average wage. For example, from some research projects the benefits from staff has the form of additional money (bonuses), from other projects the benefits has the form of additional money and also the additional workload. If we increase both wage and formal workload, the average wage will not raise. Thirdly, the total subsidy for the student is influenced not only by the coefficient of economic difficulty, but also by so-called qualitative and performance indicator ("VKM"). Fourthly, using RIV points we measure the research output, while the average wage is influenced by research inputs (institutional and specific support of research). It means that there could be a weak correlation between inputs and outputs. Finally, maybe the RVVI Methodology (RVVI, 2011) is not so good for comparison of research performance among Faculties of Economics.

If we compute research productivity of the Czech HEIs (at the level of HEIs) we would conclude that the research productivity is higher in more heterogeneous institutions (Charles University, Masaryk University) and in institutions which are more focused on technical and science branches (Czech Technical University). On the other hand, more homogeneous (University of Economics, Prague) and HEIs oriented on humanities and social sciences (University of Hradec Kralove, Jan Evangelista Purkyne University in Usti) are less efficient. These conclusions are in accordance to the results of Huzvar and Rigova (2012). 
The results can be partly explained by the method of evaluation of research activities (so-called coffee-mill) by RVVI (2011) which prefer technical and science research.

\section{Conclusion}

In this paper we presented two parts of analysis of labour productivity at higher education institutions. Firstly, variance in average wage at 20 HEIs could be explained by variance in labour productivity divided into teaching productivity (measured by adjusted number of students per academic staff) and research productivity (RIV points per academic staff). By this relation, where number of students is adjusted by the coefficients of economic difficulty, $56.1 \%$ of variance could be explained. In comparison with the results for the period between the years 2004 and 2009 (66.5\%) we explained smaller part of differences in average wages at HEIs.

From the point of view of the Faculties of Economics the variance in average wage could also be explained by variance in teaching productivity and research productivity. This model explained only $37 \%$ of the variance which was a smaller part of variance of average wage than a similar model of public HEIs. The underlying reasons could be detected in some redistribution processes, methodological issues, influence of qualitative indicators (so-called VKM), weak correlation between research money and research output and unsuitability of RVVI Methodology for comparisons among faculties of economics.

Second part of the analysis focused on the comparison of teaching productivity and labour costs of the Faculties of Economics. Almost all Faculties showed higher increase in teaching productivity than in labour costs. The highest difference was achieved at the Faculty of Informatics and Statistics, University of Economics in Prague (42.82 \%). Unfortunately, as a reverse part of the pressure on teaching productivity we should consider the issues of quality of an educational process.

Analyses of HEIs gain more importance these days. We will continue our work in this area analysing the relationship between the structure of academic staff and the structure of RIV points for instance.

\section{Acknowledgements}

This paper has been prepared under the support of the project of the University of Economics, Prague - Internal Grant Agency, project No. 19/2011 "Single-factor and multifactor productivity in context of input-output tables and composite indicators".

\section{References}

Callan, P. (2007). 'Good Policy, Good Practice. Improving Outcomes and Productivity in Higher Education: A Guide for Policymakers'. A Joint Report from The National Center for Public Policy and Higher Education and The National Center for Higher Education Management Systems. http://www. highereducation.org/reports/Policy_Practice/GPGP.pdf.

Fischer, J., Vltavská, K.(2011) ‘Labour Productivity and Labour Costs at Public Higher Education Institutions: An Empirical View on a Period 2004-2009', Proceedings of the 8th International Conference on Efficiency and Responsibility in Education (ERIE 2011), Prague, pp. 75-83.

Gates, S., Stone, A. (1997) 'Understanding Productivity in Higher Education',[Online], Available: http://www.ucop.edu/ acadinit/mastplan/ProjectH.pdf [4 Apr 2012]. 
Hindls, R., Hronová, S., Seger, J. (2004) Statistika pro ekonomy, Praha: Professional publishing.

Hužvár, M., Rigová, Z. (2012) 'Efficiency of Performance of Higher Education Institutions', Proceedings of the 15th Aplication of Mathematics and Statistics in Economy, Liberec, in print.

Jablonský, J. (2011) 'Models for Efficiency Evaluation in Education', Proceedings of the 8th International Conference on Efficiency and Responsibility in Education (ERIE 2011), Prague, pp. 110-119.

Ministry of Education, Youth and Sports (MŠMT), (2006) 'Financing of Public Higher Education Institutions 2006'. http:// www.msmt.cz/Files/vysokeskoly/financovaniVS/Rozpocet_ VS_2006_Souhrn_tabulek_1-6.xls [4 Apr 2012].

Ministry of Education, Youth and Sports (MŠMT), (2010) 'Financing of Public Higher Education Institutions 2010'. http://www.msmt.cz/uploads/soubory/vysoke_skoly/Rozpis_ rozpoctu_VS_2010_po_zvyseni_o_800_mil._12_2_10.xls [4 Apr 2012].

Ministry of Education, Youth and Sports (MŠMT) (2008a) Statistical Yearbook of Education - Employees and Labour Costs 2006/2007.

Ministry of Education, Youth and Sports (MŠMT) (2008b) Statistical Yearbook of Education - Performance Indicators 2006/2007.

Ministry of Education, Youth and Sports (MŠMT) (2012a) Statistical Yearbook of Education - Employees and Labour Costs 2010/2011.

Ministry of Education, Youth and Sports (MŠMT) (2012b) Statistical Yearbook of Education - Performance Indicators 2010/2011.
Ministry of Education, Youth and Sports (MŠMT), (2012c) 'The Law on Higher Education Institutions'. http://www.msmt.cz/ file/22282 [7 Oct 2012].

Ministry of Education, Youth and Sports (MŠMT), (2012d) The Principles and Rules of Funding of HEIs The Principles and Rules of Funding of HEIs (in Czech only), Praha. [Online], Available: http://www.msmt.cz/ekonomika-skolstvi/zasady-a-pravidlafinancovani-verejnych-vysokych-skol-pro [4 Apr 2012].

Office for National Statistics (ONS), (2005) 'Atkinson Review: Final Report. Measurement of Government Output and Productivity for the National Accounts'.

Research, Development and Innovation Council (RVVI), (2011) Methodology of Evaluation of Research Institutions Results and of Evaluation of Finished Programmes 2011 (in Czech only), Praha. [Online], Available: http://www.vyzkum.cz/FrontClanek. aspx?idsekce=608098 [4 Apr 2012].

Simpson, H. (2006) 'Productivity in Public Services', Journal of Economic Surveys, vol. 23 (2), pp. 250-276. [Online], Available: http://www.bris.ac.uk/Depts/CMPO/workingpapers/wp164. pdf [4 Apr 2012]. 
Journal on Efficiency and Responsibility in Education and Science

ISSN: 1803-1617, doi: 10.7160/eriesj.2013.060104

\section{Appendix}

\begin{tabular}{|c|c|}
\hline Abbreviation & University \\
\hline ČTU & Czech Technical University in Prague \\
\hline CULS & Czech University of Life Sciences Prague \\
\hline USB & $\begin{array}{l}\text { University of South Bohemia in České } \\
\text { Budějovice }\end{array}$ \\
\hline MU & Masaryk University \\
\hline MENDELU & Mendel University in Brno \\
\hline $\mathrm{UO}$ & University of Ostrava \\
\hline SU & Silesian University in Opava \\
\hline TUL & Technical University of Liberec \\
\hline UHK & University of Hradec Králové \\
\hline UJEP & $\begin{array}{l}\text { Jan Evangelista Purkyně University in Ústí nad } \\
\text { Labem }\end{array}$ \\
\hline $\mathrm{CU}$ & Charles University in Prague \\
\hline UPA & University of Pardubice \\
\hline PU & Palacký University Olomouc \\
\hline TBU & Tomas Bata University in Zlín \\
\hline UVPS & $\begin{array}{l}\text { University of Veterinary and Pharmaceutical } \\
\text { Sciences Brno }\end{array}$ \\
\hline VŠB-TUO & VŠB - Technical University of Ostrava \\
\hline VŠE & University of Economics, Prague \\
\hline ICT & Institute of Chemical Technology Prague \\
\hline BUT & Brno University of Technology \\
\hline UWB & University of West Bohemia \\
\hline
\end{tabular}

